\title{
PENGARUH PENDIDIKAN DAN UPAH TERHADAP TINGKAT PENGANGGURAN DI KABUPATEN SUMBAWA TAHUN 2006-2017
}

\author{
${ }^{1}$ DWI NURHASANAH, ${ }^{2}$ FAHLIA, ${ }^{3}$ ABDUL HADI ILMAN \\ ${ }^{1}$ Program Studi Ekonomi Pembanguanan, Fakultas Ekonomi dan Bisnis Universitas Teknologi Sumbawa \\ *) e- mail:fdwi.nurhasanah03@gmail.com, fahlia@uts.ac.id, abdul.hadi.ilman@uts.ac.id
}

\begin{abstract}
ABSTRAK
Penelitian ini bertujuan untuk mengetahui (1) pengaruh pendidikan terhadap tingkat pengangguran di Kabupaten sumbawa, (2) pengaruh upah terhadap tingkat pengangguran di Kabupaten sumbawa, (3) pengaruh pendidikan dan upah terhadap tingkat pengangguran di Kabupaten Sumbawa. Pendekatan yang digunakan dalam penelitian ini adalah pendekatan kuantitatif karena data yang didapat berhubungan dengan angka dan menggunakan data time series berupa data tahunan dari tahun 2006-2017. Dalam penelitian ini alat anlisis yang digunakan yaitu analisis regresi berganda dengan menggunakan alat pengolahan data program STATA. Hasil penelitian ini menunjukkan bahwa, (1) tidak teedapat pengaruh signifikan pendidikan terhadap tingkat pengangguran di Kabupaten sumbawa, (2) terdapat pengaruh signifikan upah terhadap tingkat pengangguran di Kabupaten Sumbawa, (3) pendidikan dan upah secara simultan berpengaruh terhadap tingkat pengangguran di Kabupaten Sumbawa. Hal ini ditunjukkan dengan nilai alpha 5\% atau sebesar 0.05.
\end{abstract}

Kata kunci: pendidikan, upah, tingkat pengangguran.

\section{Pendahuluan}

Negara dibentuk untuk mencapai tujuannya yaitu menyejahterakan setiap warganya untuk mencapai misi dan tujuan bernegara ini, pemilik negara (seluruh rakyat) memilih dan menunjuk penyelenggara negara, yang terdiri dari eksekutif (pemerintah), legislatif (parlemen) dan yudikatif (penyelenggara kekuasaan kehakiman). Dari ketiga kelompok penyelenggara tersebut, pemerintah adalah penyelenggara negara yang langsung berhubungan dengan kegiatan masyarakat sehari-hari.

Pemerintah di negara manapun mempunyai peranan penting dan strategis dalam penyelenggaraan kehidupan bernegara. Penyelenggaraan kehidupan bernegara bertujuan untuk mencapai tujuan bernegara, yakni untuk melindungi dan meningkatkan kualitas kehidupan dan kesejahteraan semua warganya. (Henry Faizal Noor, 2015) Indonesia merupakan negara berkembang dimana terdapat berbagai permasalahan yang sulit diatasi terutama masalah sosial ekonomi. Sehubungan dengan hal tersebut di antara permasalahan yang timbul ke permukaan berkaitan dengan pesatnya pertumbuhan penduduk, yaitu ketidakseimbangan antara pertumbuhan lapangan pekerjaan dengan semakin bertambahnya tenaga kerja setiap tahunnya. Hal itu akan menimbulkan kelebihan penawaran tenaga kerja dari pada permintaannya, sehingga memunculkan fenomena pengangguran. Di satu sisi, pengangguran menunjukkan adanya selisih antara permintaan (demand for labor) dan penawaran tenaga kerja (supply of labor) dalam suatu perekonomian (Yustika, 2005).

Pengangguran merupakan salah satu masalah yang dihadapi semua Negara di dunia sebagai akibat dari adanya kesenjangan antara jumlah penduduk usia kerja yang masuk dalam angkatan kerja dengan ketersediaan kesempatan kerja. Indonesia sendiri khususnya dalam bidang lapangan kerja membutuhkan sumber daya manusia yang berkualitas agar perusahaan dapat bersaing danberkembang pesat. Selama ini, berbagai kebijakan dibuat disetiap pemerintahan untuk menanggulangi masalah pengangguran, kebijakan yang dibuat oleh pemerintah pusat yang dalam hal ini dimentori oleh Kementerian Tenaga Kerja dan Transmigrasi (Kemenakertrans), merancang berbagai program untuk dapat mengatasi masalah pengangguran.

Masalah pengangguran saat ini menjadi masalah yang sulit untuk diatasi oleh pemerintah. Banyak warga Indonesia yang tidak memiliki pekerjaan ataudengan kata lain menjadi pengangguran. Pada tahun 2000 tingkat pengangguran terbuka meningkat dari $6.1 \%$ menjadi $10.3 \%$ atau sekitar 10.3 juta penganggur pada tahun 2005.pengangguran pada tahun 2007 turun menjadi 9,11\% dan pada tahun 2008 ini kembali turun menjadi $8.6 \%$. dan ini belum terhitung tak kurang dari 30 juta orang yang termasuk setengah menganggur karena 
bekerja kurang dari 35 jam dalam satu minggu. Pertumbuhan ekonomi rata-rata yang hanya 4.5\% selama 2000-2005 terbukti tidak mampu menyerap angkatan kerja baru sebesar $2-2.5 \%$ per tahun. Dari 102.55 juta orang yang bekerja pada Agustus 2008, status pekerjaan utama yang terbanyak adalah sebagai buruh/karyawan sebesar 28.18 juta orang (27.5\%), diikuti berusaha dibantu buruh tidak tetap sebesar 21,77 juta orang $(21.2 \%)$ dan berusaha sendiri sejumlah 20.92 juta orang (20.4\%), sedangkan yang terkecil adalah berusaha dibantu buruh tetap sebesar 3.02 juta orang (2.9\%). (Mudjarat Kuncoro: 2009, 2010). Dan berdasarkan data dari (Sakernas: 2017) jumlah angkatan kerja pada tahun 2017 sebanyak 131, 55 juta orang dari jumlah lapangan kerja yang ada. Pada tahun 2017, pengangguran terbuka menurut pendidikan yang ditamatkan terhitung masih tinggi. Sampai dengan saat ini yang menjadi sorotan utama adalah pengangguran terdidik.

Namun demikian, Leonardus saiman (2014:32) mengemukakan bahwa pengangguran-pengangguran ini bukan orang-orang yang tidak memiliki pengetahuan dan keterampilan, melainkan karena mereka ingin menjadi pekerja, sementara kesempatan kerja terbatas. Seperti yang diketahui ada banyak faktor-faktor yang mempengaruhi tingkat pengangguran. Dari beberapa ahli menjelaskan bahwa kecenderungan makin meningkatnya tingkat pendidikan akan berakibat meningkatnya pula angka pengangguran tenaga kerja terdidik dari pada bertambahnya tenaga kerja yang mempunyai produktivitas sesuai dengan kebutuhan lapangan kerja. (Sutomo, dkk, 1999). Faktor pendidikan memiliki peranan yang penting terhadap pengangguran. Dimana apabila pendidikan suatu masyarakat rendah dapat berakibat pada meningkatnya tingkat pengangguran di negara tersebut. Demikian pula sebaliknya. Hal inidisebabkan karena kurangnya sumber daya manusia yang memiliki pengetahuan, skill dan keahlian.

Dalam setiap daerah pemerintah telah menjalankan program-program yang dapat mengurangi pengangguran namun belum bisa terealisasi sesuai dengan sasaran, tidak terkecuali di daerah Kabupaten Sumbawa. Masalah pengangguran juga merupakan isu penting yang menjadi permasalahan tahunan dalam pembangunan ekonomi. Pemerintah daerah sebagai perpanjangan tangan dari pemerintah pusat juga harus mengambil bagian dalam menyelesaikan masalah pengangguran yang ada di Kabupaten Sumbawa.

Berdasarkan data yang diperoleh dari Badan Pusat Statistik Kabupaten Sumbawa bahwa jumlah Angkatan Kerja pada tahun 2017 sebanyak 214,194 orang, menurun 3.427 orang dibanding Agustus 2015 (2 tahun lalu). Komponen pembentuk Angkatan Kerja adalah penduduk yang bekerja dan penduduk yang menganggur.Penduduk yang bekerja pada Agustus 2017 sebanyak 205.672 orang, mengalami penurunan sekitar 2.817 orang dibandingkan keadaan dua tahun lalu.Begitu juga jumlah pengangguran sebanyak 8.522 orang, mengalami penurunan sekitar 610 orang disbanding dua tahun lalu.
Mengetahui kondisi tesebut tidak menutup kemungkinan bahwa pengangguran akan terus menurun. Dilihat dari pertambahan penduduk dan tingkat pendidikan yang semakin bertambah dengan tingkat pendidikan pada Agustus 2017 yang berdasarkan data dari Badan Pusat Satitistik Kabupaten Sumbawa bahwa TPT untuk diploma I/II/III paling tinggi diantara tingkat pendidkan lain yaitu sebesar 19,64 persen. TPT tertinggi berikutnya terdapat pada sekolah Menengah Kejuruan (SMK) sebesar 10,34 persen diikuti SMA Umum sebesar 6,58 persen. Dengan kata lain ada penawaran tenaga kerja yang berlebih terutama pada tingkat pendidikan tertinggi. Pekerja yang berpendidikan rendah cenderung menerima pekerjaan apa saja, seperti TPT SD dimana tingkat pendidikannya sebesar 1,44 persen.

Berdasarkan uraian diatas, dengan kedua faktor yang mempengaruhi pengangguran maka rumusan masalah penelitian ini adalah

\section{Rumusan Masalah}

Berdasarkan latar belakang diatas terdapat beberapa faktor yang memepengaruhi tingkat pengangguran. Adapun rumusan masalah dalam penelitian ini yaitu bagaimana pengaruh pendidikan dan upah terhadap pengangguran di Kabupaten Sumbawa?

\section{Tujuan Penelitian}

Adapun tujuan masalah dari penelitian ini yaitu untuk mengetahui pengaruh dari pendidikan dan upah terhadap pengangguran di Kabupaten Sumbawa.

\section{TINJAUAN PUSTAKA}

\section{Kajian Teori}

1. Pengertian pengangguran

Sadono Sukirno (2004: 28) mengatakan bahwa pengangguran adalah seseorang yang sudah digolongkan dalam angkatan kerja, yang secara aktif sedang mencari pekerjaan pada suatu tingkat upah tertentu, tetapi tidak dapat memperoleh pekerjaan yang diinginkan. Tingkat pengangguran menunjukkan persentase dari individuindividu yang ingin bekerja namun tidak memiliki perkerjaan. Seseorang dianggap menjadi penganggur jika tidak bekerja namun masih menunggu untuk mendapatkan pekerjaan.

Menurut Badan Pusat Statistik dalam indikator ketenagakerjaaan, pengangguran adalah penduduk yang tidak bekerja namun sedang mencari pekerjaan atau sedang mempersiapkan suatu usaha baru atau penduduk yang tidak mencari pekerjaan karena sudah diterima bekerja tetapi belum mulai bekerja.

Berdasarkan beberapa pendapatan diatas pengangguran adalah orang yang termasuk dalam angkatan kerja tetapi belum mendapatkankan pekerjaan dan ada orang yang tidak ingin mencari pekerjaan.

\section{Hubungan Antar Variabel}

2. Hubungan Tingkat Pendidikan Terhadap
Pengangguran


Berkaitan dengan upaya pencapaian pembangunan ekonomi yang berkelanjutan, sektor pendidikan memainkan peranan sangat strategis dalam mendukung proses produksi dan aktivitas ekonomi lainnya. Dalam konteks ini, pendidikan dianggap sebagai alat untuk mencapai target yang berkelanjutan, karena dengan pendidikan yang lebih tinggi, jumlah tenaga kerja yang terserap akan meningkat sehingga jumlah pengangguran berkurang. Dengan demikian, aktivitas pembangunan dapat tercapai sehingga peluang untuk meningkatkan kualitas hidup di masa mendatang akan lebih baik. Analisis atas investasi dalam bidang pendidikan menyatu dalam pendekatan modal manusia. Modal manusia (human capital) adalah istilahyang sering digunakan oleh para ekonom untuk pendidikan, kesehatan, dan kapasitas manusia lainnya yang dapat meningkatkan produktivitas jika hal-hal tersebut ditingkatkan. Pendidikan memainkan kunci dalam membentuk kemampuan untuk menyerap teknologi modern dan untuk mengembangkan kapasitas seseorang agar tercipta pertumbuhan serta pembangunan yang berkelanjutan (Todaro dan Smith, 2004).

1. Pengertian Upah

Menurut Peraturan Pemerintah No. 78 Tahun 2015 tentang Pengupahan, Pasal 41 ayat 2, "upah minimum merupakan upah bulanan terendah yang terdiri atas: a. upah tanpa tunjangan; atau b. upah pokok termasuk tunjangan tetap". Peraturan Pemerintah ini juga menegaskan bahwa upah minimum hanya berlaku bagi pekerja/buruh dengan masa kerja kurang dari 1 (satu) tahun pada perusahaan yang bersangkutan. Sementara itu, upah bagi pekerja/buruh dengan masa kerja 1 (satu) tahun atau lebih dirundingkan secara bipartit antara pekerja dengan pengusaha di perusahaan yang bersangkutan. Pada Undang-undang No.13 tahun 2003 tentang Ketenagakerjaan, upah didefinisikan sebagai hak pekerja/buruh yang diterima dan dinyatan dalam bentuk uang sebagai imbalan dari pengusaha atau pemberi kerja kepada pekerja/buruh yang ditetapkan dan dibayarkan menurut suatu perjanjian kerja, kesepakatan, atau peraturan perundang-undangan termasuk tunjangan bagi pekerja/buruhdan keluarganya atas suatu pekerjaan atau jasa yang telah atau akan dilaksanakan.

2. Hubungan Tingkat Upah Terhadap Pengangguran

Todaro (2000, terjemahan Haris Munandar, 2000), mendefinisikan semakin tinggi tingkat upah yang ditawarkan kepada tenaga kerja maka akan menurunkan tingkat penyerapan tenaga kerja. Hal ini berarti bahwa pengangguran akan meningkat. Pendapat yang sama dikemukakan oleh Sumarsono (2003), yaitu besar kecilnya upah akan mempengaruhi tinggi rendahnya biaya produksi perusahaan. Biaya produksi yang tinggi meningkatkan harga produk yang pada akhirnya membuat permintaan terhadap produk berkurang. Kondisi ini memaksa produsen untuk mengurangi jumlah produk yang dihasilkan, yang selanjutnya juga dapat mengurangi permintaan tenaga kerja, termasuk pemutusan hubungan kerja yangmengakibatkan meningkatnya jumlah pengangguran.

\section{METODOLOGI PENELITIAN}

Jenis penelitian

Data yang digunakan dalam penelitian ini adalah data sekunder yang dipublikasikan oleh lembaga-lembaga atau institusi-institusi anatara lain Badan Pusata Statistik dan Badan Perencanaan Pembangunan Daerah Kabupaten sumbawa. Pendekatan yang digunakan dalam penelitian ini adalah pendekatan kuantitatif karena data yang didapat berhubungan dengan angka dan menggunakan data time series berupa data tahunan dari tahun 20062017. Data yang digunakan adalah: (1) Rata-rata lama sekolah, (2) upah (UMR), (3) tingkat pengangguran terbuka.

\section{Metode Analisis}

Dalam pengolahan penelitian ini menggunakan model analisis regresi berganda. Adapun rumusnya adalah: $\mathrm{Y}=\mathrm{a}+\mathrm{b}_{1} \mathrm{X}_{1}+\mathrm{b}_{2} \mathrm{X}_{2}+\mathrm{b}_{\mathrm{n}} \mathrm{X}_{\mathrm{n}}$

Hasil Analisis Regresi Berganda

\begin{tabular}{|l|l|l|l|l|}
\hline Variabel & Coefisien & Std eror & t & Sig t \\
\hline Konstatnta & 21.55335 & 12.93441 & 1.67 & 0.130 \\
\hline Pendidikan & -1.805946 & 1.871176 & - & 0.960 \\
\hline Upah & $-2.90 \mathrm{e}-06$ & $1.12 \mathrm{e}-06$ & - & 0.030 \\
\hline
\end{tabular}

Sumber: Hasil Olah Data,2019

TPT $=21.55335-1.805946$ Pend -0.0000029 Upah Dari persamaan diatas dapat dijelaskan sebagaiberikut:

1. Ketika pendidikan naik satu tahun, maka tingkat pengangguran terbuka akan turun sebesar 1.805496.

2. Ketika upah naik satu rupiah, maka tingkat pengangguran terbuka akan turun sebesar 0.0000029 .

3. Ketika pendidikan dan upah bernilai 0 maka tingkat pengangguran terbuka akan sebesar 21.55335 ribu jiwa.

Pada hasil regresi sebagaimana disebutkan pada tabel 4.3 diatas, untuk menguji hipotesisi pengaruh secara bersamasama (simultan) digunakan uji $\mathrm{F}$ dengan menggunakan derajat kepercayaan (degree off freedom) 0.05. sedangkan untuk menguji hipotesis secara individu (parsial) digunakan uji $\mathrm{t}$ yaitu menguji secara parsial variabel bebas terhadap variabel terikat.

\subsubsection{Uji F (signifikan secara simultan)}

Pada Uji F akan memperlihatkan pengaruh atau hubungan antar variabel independen secara bersama-sama (simultan) terhadap variabel dependen. Yaitu pengaruh pendidikan dan upah terhadap tingkat pengangguran di Kabupaten sumbawa pada tahun 2006-2017. Adapun hasil dari Uji F pada tabel dibawah ini yaitu: 


\begin{tabular}{|l|l|}
\hline R-squared & 0.7126 \\
\hline Adjusted R-squared & 0.6487 \\
\hline Rood MSE & 0.9638 \\
\hline F-hitung & 11.16 \\
\hline Prob $>$ F & 0.0037 \\
\hline
\end{tabular}

Diketahui bahwa nilai F-hitung sebesar 11.16 dengan Prob F 0.0037. Nilai Prob F lebih kecil dari 0.05 $(0.0037<0.05)$ nilai F-hitung $>$ F-tabel pada derajat kepercayaan 0.05 uji satu sisi. Dimana 11.16 $>4.96$. Artinya bahwa secara bersama-sama (simultan) variabel bebas yang terdiri dari pendidikan dan upah berpengaruh signifikan terhadap Tingkat Pengangguran di Kabupaten Sumbawa dari tahun 2006-2017. Pada hasil regresi uji F-hitung sebesar 11.16. dengan menggunakan derajat kepercayaan (degree off freedom) 0.05. Dengan demikian hipotesis yang menduga secara bersama-sama variabel pendidikan dan upah berpengaruh signifikan terhadap veriabel Tingkat Pengangguran terbukti kebenarannya. Jadi untuk hipotesis ini diterima. Sama halnya dengan penelitian yang dilakukan oleh Isnayanti dan Arna Ritoga (2017) yang menyatakan bahwa upah dan pendidikan berpengaruh (signifikan) terhadap variabel dependen tingkat pengangguran ( $\mathrm{Y}$ ) pada tingkat keyakinan $95 \%(\alpha=5 \%)$.

Uji t (signifikan secara parsial)

Pada variabel pendidikan diperoleh nilai t-hitung sebesar -0.97 dengan signifikan $\mathrm{t}$ sebesar 0.360 . karena t-hitung lebih kecil dari t-tabel $(-0.97<1.812)$ atau signifikan $\mathrm{t}$ lebih besar dari $5 \%(0.360>0.05)$, maka secara parsial variabel pendidikan tidak terdapat pengaruh signifikan terhadap variabel Tingkat Pengangguran Terbuka atau dapat dikatakan bahwa terjadi penerimaan Ha. Hal ini sejalan dengan penelitian yang dilakukan oleh Dahma Amar Ramdhan dkk (2017) yang mengatakan bahwa pendidikan tidak berpengaruh terhadap tingkat pengangguran. Dan bertolak belakang dengan pendapat dari Todaro dan smith (2004) yang mengatakan bahwa pendidikan dianggap sebagai alat untuk mencapai target yang berkelanjutan, karena dengan pendidikan yang lebih tinggi, jumlah tenaga kerja yang terserap akan meningkat sehingga jumlah pengangguran berkurang. Dengan demikian, aktivitas pembangunan dapat tercapai sehingga peluang untuk meningkatkan kualitas hidup di masa mendatang akan lebih baik. Analisis atas investasi dalam bidang pendidikan menyatu dalam pendekatan modal manusia. Modal manusia (human capital) adalah istilah yang sering digunakan oleh para ekonom untuk pendidikan, kesehatan, dan kapasitas manusia lainnya yang dapat meningkatkan produktivitas jika hal-hal tersebut ditingkatkan. Pendidikan memainkan kunci dalam membentuk kemampuan untuk menyerap teknologi modern dan untuk mengembangkan kepastian seseorang agar tercipta pertumbuhan serta pembangunan yang berkelanjutan. Dalam konteks ini, pendidikan dianggap sebagai alat untuk mencapai target yang berkelanjutan, karena dengan pendidikan yang lebih tinggi, jumlah tenaga kerja yang terserap akan meningkat sehingga jumlah pengangguran berkurang.

Pada variabel upah diperoleh nilai t-hitung sebesar -2.58 dengan signifikan t sebesar 0.030. karena nilai t-hitung lebih besar dari t-tabel $(-2.58>1.812)$ atau signifikan t lebih kecil dari $5 \%(0.030<0.05)$, maka secara parsial variabel Upah berpengaruh terhadap Tingkat Pengangguran Terbuka atau dapat dikatakan H0 diterima. Penelitian ini sejalan dengan pendapat yang dikemukakan oleh Todaro (2002) yang menyatakan bahwa semakin tinggi tingkat upah yang ditawarkan kepada tenaga kerja maka akan menurunkan tingkat penyerapan tenaga kerja, hal ini berarti bahwa pengangguran akan meningkat.

\section{2}

\section{oefisien Determinasi atau R-Squaer $\left(R^{2}\right)$}

Berdasarkan tabel dari hasil pengolahan data diperoleh koefisien determinasi $\mathrm{R}^{2}$ sebesar 0.7126. hal ini menunjukkan bahwa variabel bebas pendidikan (x1) dan upah (X2) yang diduga sebagai faktor-faktor yang berpengaruh terhadap variabel terikat yaitu tingkat pengangguran di kabupaten Sumbawa tahun 20062017 sebesar $71.26 \%$ sedangkan sisanya28.74\% dipengaruhi oleh variabel lain yang tidak dimasukkan dalam model penelitian ini atau terangkum dalm kesalahan pengganggu (e). Faktor pengganggu tersebut antara lain yang juga mempengaruhi Tingkat Pengangguran di Kabupaten Sumbawa.

\section{KESIMPULAN}

Dalam penelitian ini untuk melihat adanya pengaruh dari faktor pendidikan peneliti menggunakan data Rata-Rata Lama Sekolah (RLS) Kabupaten Sumbawa. Sedangkan faktor upah peneliti menggunakan data Upah dari upah itu sendiri dan faktor tingkat pengangguran peneliti menggunakan data Tingkat Pengangguran Terbuka di Kabupaten Sumbawa. Dalam penelitian ini peneliti menggunakan data tahunan (time series) dengan periode penelitian mulai dari tahun 2006 hingga tahun 2017. Adapun hasil estimasi yang dilakukan dengan menggunakan software Stata ver 11 memberikan kesimpulan berdasarkan pada tujuan penelitian yaitu sebagai berikut:

a. faktor pendidikan tidak berpengaruh terhadap tingkat pengangguran di Kabaupaten Sumbawa. Dengan hasil t-hitung $-0.97<\mathrm{t}$-tabel 1.812 , dan besarnya pengaruh pendidikan sebesar $17.26 \%$.

b. faktor upah berpengaruh terhadap tingkat pengangguran di kabupaten sumbawa. Dengan hasil t-hitung $-2.58>$ t-tabel 1.812 , dan besarnya pengaruh 
upah sebesar 17.26\%. Hal ini sejalan dengan pendapat yang dikemukakan oleh Sumarsono (2003), yaitu besar kecilnya upah akan mempengaruhi tinggi rendahnya biaya produksi perusahaan. Biaya produksi yang tinggi meningkatkan harga produk yang pada akhirnya membuat permintaan terhadap produk berkurang. Kondisi ini memkasa produsen untuk mengurangi jumlah produk yang dihasilkan, yang selanjutnya juga dapat mengurangi permintaan tenaga kerja, termasuk pemutusan hubungan kerja yang mengakibatkan meningkatnya jumlah pengangguran.

c. faktor pendidikan (rata-rata lama sekolah) dan upah (UMR) berpengaruh signifikan terhadap tingkat pengangguran di Kabupaten Sumbawa. Dengan nilai F-hitung sebesar 11.16 dengan Prob F 0.0037 dimana nilai Prob F lebih kecidari 0.05 $(0.0037<0.05)$. Artinya secara simultan variabel pendidikan dan upah berpengaruh terhadap tingkat pengangguran.

Daftar Pustaka

Noor Faizal Henry, 2015, Ekonomi Publik: Ekonomi untuk kesejahteraan rakyat, Jakarata.

Kuncoro Mudjarad, 2009, Ekonomika Indonesia: Dinamika lingkungan bisnis di tengah krisis global, UPP STIM YKPN Yogyakarta.

Arsyad Lincolin, 2016, Ekonomi Pembangunan, UPP STIM YKPN Edisi Ke 5.

Yustika, Ahmad Erani, 2005. Perekonomian Indonesia; Deskripsi, Preskripsi, dan Kebijakan. Bayu Media, Malang.

SaimanLeornadus, 2009, Kewirausahaan :Teori, Prkatek, danKasus-kasus, Jakarta, SalembaEmpat.

Sutomo, Vincent Hadiwiyono dan Prihartini BS. 1999. Analisis Faktor-Faktor yang Mempengaruhi Lama Mencari Kerja Terdidik di Kabupaten Klaten Tahun 1996. Skripsi.

Poyoh Arfan, G. H. (2017). Faktor-faktor yang mempengaruhi tingkat pengangguran di Provinsi Sulawesi Utara. Volume 13 Nomor 1A, Januari 2017: 55-66.

Ramadhan Amar Dahma., Setiyadi Djoko., Wijaya Adi,. (2017). Faktor-faktor yang mempengaruhi tingkat pengangguran dan kemiskinan di Kota Samarinda.

Moekijat. 1993. Sistem Akuntansi. Edisi Ketiga. Yogyakarta : BPFE, YKPN.

Badan Pusat Statistik. (2005). Sumbawa Dalam Angka. Diakses Desember 2005-2016.

Dinas Ketenagakerjaan dan Transmigrasi. (2018). Daftar upah buruh/pekerja pertahun. Kabupaten sumbawa

Sukirno, Sadono. (2004), Makroekonomi Teori Pengantar, Edisi Ketiga.Penerbit Raja Grafindo Persada, Jakarta.
Sumarsono, Sony, 2003. Ekonomi Manajemen SumberHaris Munandar, Jakarta: Erlangga.

Yacoub, Yarlina (2012). “ Pengaruh Tingkat Pengangguran terhadap Tingkat kemiskinan Kabupaten/Kota di Provinsi Kalimantan Barat”. Universitas Tanjungpura Pontianak : volume 8, nomor 3, Oktober 2012 hal 176-185.

Suprayitno, Joko (2017). "Pengaruh Tingka Pendidikan terhadap Jumlah pengangguran di Kota Semarang." Volume 3, Agustus 2017 hal- 50-62.

Sugiyono. (2014). Metode Penelitian Pendidikan Pendekatan Kuantitatif, Kualitatif dan R\&D.Bandung:AlfabetaBandung.

Arikunto, S. (2010).ProsedurPenelitian, RinekaCipta. Jakarta.

Sujarweni Wiratna. V, 2015, SPSS Untuk Penelitian, Pustaka Baru Press Yogyakarta.

Kuncoro, Mudrajad (2007), Metode Riset Untuk Bisnis dan Ekonomi, Erlangga Jakarta

Kuncoro, Mudrajad. 2005. Ekonomi Pembangunan Teori, Masalah dan Kebijakan. Yogyakarta: UPP AMP YKPN.

Simanjuntak, Payaman J. 1985. Pengantar Ekonomi SUmber Daya Manusia. Penerbit FEUI (Fakultas Ekonomi Universitas Indonesia): Jakarta

Mankiw, Gregory N. 2000. Teori Makro Ekonomi Ed. 4.Jakarta: Erlangga. 2003. Economics Fifth Edition. New York: Worth Publishers 41 Madison Avenue.

Peraturan pemerintah No. 78 Tahun 2015 tentang pengupahan, pasal 41 ayat 2 .

Undang-Undang N0.13 Tahun 2003 tentang Ketenagakerjaan.

https://www.prasetyowijaya.com/2009/02/scatterplot.html? $\mathrm{m}=1$

http://data.rosihanari.net/python/fungsi-dan-caramembuat-scatter-plot-di-python.py Daya Manusia dan Ketenagakerjaan. Yogyakarta: Graha Ilmu.

Todaro, Michael P. dan Smith, Stephen C., 2004. Pembangunan Ekonomi di Dunia Ketiga. Edisi Kedelapan, Jilid 1, Terjemahan 
IFRI Vo1 n4 No ก) nn 22_?7 
IFRI Vo1 n4 No ก) nn 22_?7 
IFRI Vn1 n4 No ก) nn 23.?7 
JEBI Vol. 04, No.01, pp. 1-8 